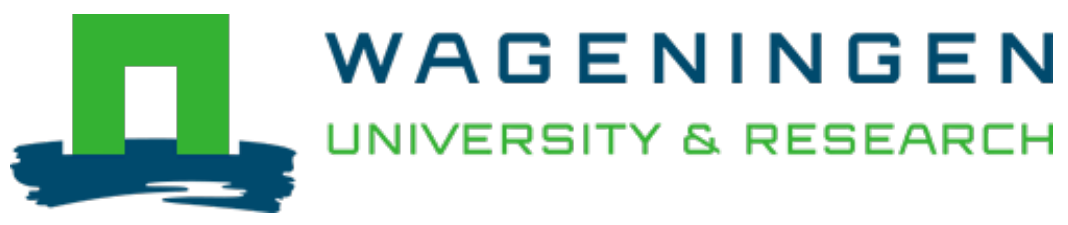

\title{
Diversity and food quality properties of farmers' varieties of sorghum from Bénin
}

Journal of the Science of Food and Agriculture

Kayodé, A.P.P.; Linnemann, A.R.; Nout, M.J.R.; Hounhouigan, J.D.; Stomph, T.J. et al

https://doi.org/10.1002/jsfa.2451

This article is made publicly available in the institutional repository of Wageningen University and Research, under the terms of article $25 \mathrm{fa}$ of the Dutch Copyright Act, also known as the Amendment Taverne. This has been done with explicit consent by the author.

Article $25 \mathrm{fa}$ states that the author of a short scientific work funded either wholly or partially by Dutch public funds is entitled to make that work publicly available for no consideration following a reasonable period of time after the work was first published, provided that clear reference is made to the source of the first publication of the work.

This publication is distributed under The Association of Universities in the Netherlands (VSNU) 'Article $25 \mathrm{fa}$ implementation' project. In this project research outputs of researchers employed by Dutch Universities that comply with the legal requirements of Article $25 \mathrm{fa}$ of the Dutch Copyright Act are distributed online and free of cost or other barriers in institutional repositories. Research outputs are distributed six months after their first online publication in the original published version and with proper attribution to the source of the original publication.

You are permitted to download and use the publication for personal purposes. All rights remain with the author(s) and / or copyright owner(s) of this work. Any use of the publication or parts of it other than authorised under article $25 \mathrm{fa}$ of the Dutch Copyright act is prohibited. Wageningen University \& Research and the author(s) of this publication shall not be held responsible or liable for any damages resulting from your (re)use of this publication.

For questions regarding the public availability of this article please contact openscience.library@wur.nl 


\title{
Diversity and food quality properties of farmers' varieties of sorghum from Bénin
}

\author{
AP Polycarpe Kayodé, ${ }^{1}$ Anita R Linnemann, ${ }^{2}$ MJ Rob Nout, ${ }^{2 *}$ \\ Joseph D Hounhouigan, ${ }^{1}$ Tjeerd Jan Stomph ${ }^{3}$ and Marinus JM Smulders ${ }^{4}$ \\ ${ }^{1}$ Faculté des Sciences Agronomiques, Université d'Abomey-Calavi, 01 BP 526 Cotonou, Bénin \\ ${ }^{2}$ Agrotechnology and Food Sciences, Wageningen University, PO Box 8129, 6700 EV Wageningen, The Netherlands \\ ${ }^{3}$ Plant Sciences, Wageningen University, PO Box 430, 6700 AK Wageningen, The Netherlands \\ ${ }^{4}$ Plant Research International, Wageningen UR, PO Box 16, 6700 AA Wageningen, The Netherlands
}

\begin{abstract}
Farmers' varieties of sorghum from three communities in different regions of northern Bénin were analysed for their food quality and agro-morphological properties, and also for their genetic diversity using amplified fragment length polymorphism (AFLP). Farmers' varieties of sorghum differed greatly with respect to their morphology and agronomic and food traits. Most of the varieties had long $(>200 \mathrm{~cm})$ stems $(87 \%)$, loose panicles $(79 \%)$ and a red or pink colour $(52 \%)$. Most were susceptible to drought $(54 \%)$ and to attacks by striga (79\%), insects $(99 \%)$ and birds (77\%). Farmers evaluated the quality of the seeds for preparing porridges as being high for $60 \%$ of the varieties and $26 \%$ of the varieties were regarded as suitable for making beverages. Late-maturing, large-seeded, red or pink varieties are preferred by farmers for porridges and beverages. Gene diversity among varieties within regions, as measured by neutral markers, was similar for the three regions $(0.211-0.240)$. However, across regions the short $(<150 \mathrm{~cm})$ stem varieties showed relatively high genetic diversity compared with long or medium stem varieties $(0.378$ vs $0.184-0.216$ for long-medium stem varieties). Genetic differentiation $\left(F_{\text {st }}\right)$ among regions and among stem lengths of varieties was significant and ranged between 0.086 and 0.135 . Grain colour, stem length and panicle shape varied significantly with the region/stem length and correlated with the genetic differentiation of regions. No relationship could be detected between the genetic differentiation of the varieties and their food quality as expressed by the farmers. Implications of the findings for crop conservation and breeding are discussed.
\end{abstract}

(C) 2006 Society of Chemical Industry

Keywords: sorghum; quality; genetic biodiversity; porridge; beverage

\section{INTRODUCTION}

Sorghum [Sorghum bicolor (L.) Moench] is an important staple food for millions of people in semiarid regions of West Africa. ${ }^{1}$ The crop is relatively drought tolerant and well adapted to low-input conditions prevailing in this zone. High food demand favoured by rapid population growth and changes in agro-ecological conditions necessitate the breeding of new varieties that combine adaptation to the agro-ecological constraints, for instance drought, the occurrence of pests and diseases and appropriateness to specific end-use. ${ }^{2}$ Compared with other cereals, sorghum breeding has been neglected in recent decades. New high-yielding maize varieties that are tolerant to semi-arid zones have been bred and distributed but sorghum varieties are still maintained and widely produced by local farmers for their own consumption. ${ }^{3,4}$ Although total sorghum production ranks fifth in cereals, ${ }^{5}$ the great majority of the production is consumed locally. This indicates the strategic role of sorghum for household food security.

In sorghum-producing areas worldwide, most of the varieties currently managed by farmers are local materials that have been selected over the years following relevant criteria for the users, i.e. farmers, processors and consumers. This approach created a large number of farmers' varieties of sorghum that were reported to be diverse in terms of their agromorphology and food quality. ${ }^{2,3}$ For example, farmers in northern Bénin could differentiate 'varieties' based on morphological characteristics (seed colour, panicle shape, stem length), tolerance to diseases and pests [insects, birds, striga (Striga asiatica)] and suitability for the preparation of specific foods (porridges, beverages). ${ }^{3}$ With respect to efficient breeding, the conservation of genetic resources is important, since

* Correspondence to: MJ Rob Nout, Agrotechnology and Food Sciences, Wageningen University, PO Box 8129, 6700 EV Wageningen, The Netherlands

E-mail: rob.nout@wur.nl

Contract/grant sponsor: Wageningen University North-South Interdisciplinary Research and Education Fund (INREF)

Contract/grant sponsor: International Foundation for Science; contract/grant number: E-3736

(Received 19 May 2005; revised version received 16 July 2005; accepted 7 December 2005)

Published online 29 March 2006 
different farmers' varieties may bear advantageous genes that are especially useful in resistance breeding and in terms of quality traits. ${ }^{6}$ However, the success of any genetic conservation and breeding programme depends on understanding the distribution of genetic diversity present in the gene pool. ${ }^{7}$ In addition, the traditional farmers' knowledge can be an appreciated instrument in the utilisation and development of new varieties. ${ }^{8,9}$ Therefore, the assessment of the genetic diversity of local crops in association with the farmers' perception of their characteristics could provide insight into their potential use and ensure rapid adoption of the improved germplasm by growers. ${ }^{10}$

Amplified fragment length polymorphism (AFLP) ${ }^{11}$ is a powerful tool for genetic diversity analysis. This technique has been used to determine genetic diversity in several crops, including sorghum. ${ }^{2,12}$ The high frequency of identifiable polymorphic markers and their reproducibility make this technique an attractive tool for detecting polymorphism and for determining genetic linkages among individuals. ${ }^{13}$

In the present study, farmers' perception and knowledge of the sorghum varieties in Bénin was surveyed and their genetic diversity was evaluated with the aim of identifying possible relationships between genotypes and their suitability for the preparation of specific food items. Implications of the findings for the conservation and improvement of sorghum varieties are discussed.

\section{MATERIALS AND METHODS}

\section{Field survey and seed collection}

The sorghum varieties in use in northern Bénin were accessed in September 2002. The term 'farmers' variety' here designates a landrace that is a local variety, developed and/or maintained by farmers in particular ecological and agro-socioeconomic conditions. ${ }^{14}$ Three farming communities were included in this study, i.e. Banikoara $\left(11^{\circ} 15^{\prime} \mathrm{N}, 2^{\circ} 23^{\prime} \mathrm{E}\right)$, Toucountouna $\left(10^{\circ} 27^{\prime} \mathrm{N}, 1^{\circ} 22^{\prime} \mathrm{E}\right)$ and Djougou $\left(9^{\circ} 43^{\prime} \mathrm{N}\right.$, $\left.1^{\circ} 41^{\prime} \mathrm{E}\right)$. Ninety farmers were interviewed using a questionnaire to collect information about the local names of varieties and the relevant descriptors of these varieties. The descriptors related to (1) agronomic characteristics: maturity, susceptibility to striga and resistance to insects and drought; (2) morphological properties: stem length (long $>200 \mathrm{~cm}$, medium or short $<150 \mathrm{~cm}$ ), panicle shape (loose or compact), grain size and colour; (3) suitability for preparing tchoukoutou (a west African sorghum beer), dibou (a thick sorghum porridge) and sorou (a granulated thin sorghum porridge); and (4) medicinal value. Farmers evaluated the suitability of the varieties to prepare food on the basis of a three-point category scale: $1=$ low quality, $2=$ medium quality and $3=$ high quality. This phase generated a list of 111 farmers' varieties with their attributes.

In December 2002, at harvesting, a second field visit to the same group of farmers was organised for seed collection and characterisation. A total of 72 farmers' varieties were randomly sampled in the three communities and questionnaires were completed for 61 of them. Farmers who provided varieties were asked to describe them on the basis of the key descriptors identified previously and to score their properties on predefined modalities (Table 1). For each variety, a description was given by two knowledgeable farmers, who were selected on the basis of recommendations given by an extension worker and fellow villagers. Whenever the information on a given variety was at variance, a third farmer was asked for a description. Eight focus group discussions were performed to complete the survey.

\section{DNA isolation and AFLP analyses of collected varieties}

Seeds from one or two branches of single panicles of all accessions were sown, one line per accession, in trays with a 1:1 mixture of sand and soil in a glasshouse at Wageningen, The Netherlands. The soil was well watered and plants were grown at $28-20{ }^{\circ} \mathrm{C}$ day-night temperature and $90 \%$ relative humidity for 2 weeks, until plants reached the four leaves stage. Per accession, leaves were sampled on five of the emerged seedlings and freeze-dried for later processing. For DNA extraction, a small piece $\left(1 \mathrm{~cm}^{2}\right)$ of the freeze-dried leaf tissue was ground with four glass pearls in a Retsch shaking mill, followed by DNA extraction. ${ }^{15}$ The AFLP method $^{11}$ was performed essentially as described, ${ }^{16}$ with separation and detection on a LI-COR 4300 (LI-COR, Lincoln, Nebraska). Approximately 80 EcoRI/MseI primer combinations were tested on four samples. Suitable combinations were selected based on the number of unambiguously scorable polymorphic bands. Finally, two primer combinations were selected for analysis: $E c o$ RI-AAC/MseI-CCC and $E c o$ R1-ACA/MseI-CTG.

\section{Data analysis}

The survey data were analysed using the statistical program SPSS 11.0 (SPSS, Chicago, Illinois). The food quality modalities, i.e. low, medium and high, were ranked on a scale from 1 to 3 and the oneway analysis of variance (ANOVA) model was used to compare means between groups applying the least significant difference (LSD) test.

For the genetic data, presence (1) or absence (0) of each polymorphic AFLP band was scored for all genotypes. AFLP-SURV version $1.0^{17}$ was used to calculate gene diversity statistics and to estimate the significance of the $F_{\text {st }}$ estimates. Principal coordinate analysis (PCO) was carried out based on the similarity matrix using NTSYSpc 2.10j (Exeter Software, Setauket, NY). Tests for correlations between genetic variation and populations or traits were performed by analysis of molecular variance (AMOVA) using AMOVA $1.55 .{ }^{18}$ 
Table 1. Frequency distribution (\%) of sorghum varieties following agromorphology and food quality traits and separating the tall ( $L$ ) and short (S) sorghum types

\begin{tabular}{|c|c|c|c|c|c|c|c|c|}
\hline \multirow[b]{2}{*}{ Characteristic } & \multirow[b]{2}{*}{ Modality } & \multicolumn{4}{|c|}{ Type $\mathrm{L}^{\mathrm{a}}$} & \multicolumn{3}{|c|}{ Type $S^{b}$} \\
\hline & & $\begin{array}{c}\text { Banikoara } \\
(n=25)\end{array}$ & $\begin{array}{l}\text { Toucountouna } \\
\quad(n=14)\end{array}$ & $\begin{array}{l}\text { Djougou } \\
(n=14)\end{array}$ & $\begin{array}{c}\text { Total } \\
(n=53)\end{array}$ & $\begin{array}{l}\text { Toucountouna } \\
\quad(n=2)\end{array}$ & $\begin{array}{c}\text { Djougou } \\
(n=6)\end{array}$ & $\begin{array}{l}\text { Total } \\
(n=8)\end{array}$ \\
\hline \multirow{2}{*}{ Panicle shape } & Compact & 36 & 0 & 0 & 17 & 50 & 50 & 50 \\
\hline & Loose & 64 & 100 & 100 & 83 & 50 & 50 & 50 \\
\hline \multirow{3}{*}{ Maturity } & Early & 32 & 43 & 36 & 36 & 50 & 0 & 12 \\
\hline & Intermediate & 12 & 7 & 7 & 9 & 50 & 33 & 50 \\
\hline & Late & 56 & 50 & 57 & 55 & 0 & 67 & 38 \\
\hline \multirow[t]{3}{*}{ Drought reaction } & Resistant & 32 & 57 & 50 & 43 & 0 & 33 & 25 \\
\hline & Intermediate & 8 & 0 & 7 & 6 & 0 & 0 & 0 \\
\hline & Susceptible & 60 & 43 & 43 & 51 & 100 & 67 & 75 \\
\hline \multirow[t]{3}{*}{ Striga reaction } & Resistant & 4 & 14 & 7 & 8 & 0 & 0 & 0 \\
\hline & Intermediate & 8 & 14 & 21 & 13 & 0 & 33 & 25 \\
\hline & Susceptible & 88 & 73 & 72 & 79 & 100 & 67 & 75 \\
\hline \multirow[t]{3}{*}{ Reaction to insects } & Resistant & 0 & 0 & 0 & 0 & 50 & 0 & 12 \\
\hline & Susceptible & 64 & 100 & 100 & 83 & 50 & 100 & 88 \\
\hline & Unknown & 36 & 0 & 0 & 17 & 0 & 0 & 0 \\
\hline \multirow[t]{2}{*}{ Bird attack } & Low & 28 & 14 & 7 & 19 & 50 & 50 & 50 \\
\hline & High & 72 & 86 & 93 & 81 & 50 & 50 & 50 \\
\hline \multirow[t]{2}{*}{ Medicinal value } & Used & 68 & 21 & 36 & 47 & 100 & 67 & 63 \\
\hline & Not Used & 32 & 79 & 64 & 53 & 0 & 33 & 37 \\
\hline \multirow[t]{3}{*}{ Grain size } & Large & 40 & 57 & 57 & 49 & 0 & 67 & 50 \\
\hline & Medium & 56 & 7 & 29 & 36 & 50 & 33 & 38 \\
\hline & Small & 4 & 36 & 14 & 15 & 50 & 0 & 12 \\
\hline \multirow[t]{4}{*}{ Grain colour } & Red & 12 & 7 & 29 & 15 & 0 & 0 & 0 \\
\hline & Pink & 24 & 72 & 50 & 43 & 0 & 16 & 12 \\
\hline & White & 56 & 21 & 21 & 38 & 50 & 16 & 25 \\
\hline & Yellow & 8 & 0 & 0 & 4 & 50 & 67 & 63 \\
\hline \multirow[t]{3}{*}{ Dibou quality } & High & 52 & 64 & 71 & 60 & 0 & 17 & 12 \\
\hline & Medium & 28 & 36 & 29 & 30 & 0 & 33 & 25 \\
\hline & Low & 20 & 0 & 0 & 10 & 100 & 50 & 63 \\
\hline \multirow[t]{3}{*}{ Tchoukoutou quality } & High & 16 & 43 & 36 & 28 & 0 & 17 & 12 \\
\hline & Medium & 36 & 14 & 43 & 32 & 0 & 33 & 25 \\
\hline & Low & 48 & 43 & 21 & 40 & 100 & 50 & 63 \\
\hline \multirow[t]{3}{*}{ Sorou quality } & High & 56 & 57 & 71 & 60 & 0 & 0 & 0 \\
\hline & Medium & 28 & 19 & 29 & 25 & 0 & 50 & 50 \\
\hline & Low & 16 & 29 & 0 & 15 & 100 & 50 & 50 \\
\hline
\end{tabular}

${ }^{a}$ Type L, long (>200 cm)-medium stem varieties; type S, short $(<150 \mathrm{~cm})$ stem varieties.

\section{RESULTS AND DISCUSSION}

\section{Farmers' characterisation of varieties}

The farmers' varieties of sorghum collected in the three farming communities differed greatly with respect to their morphology and agronomic and food traits (Table 1). Most of the varieties had long stems (87\%), loose panicles $(79 \%)$, large seeds $(49 \%)$ and a red or pink colour $(52 \%)$. In addition, most of the varieties were considered to be susceptible to drought (54\%) and attacks by striga (79\%), insects (99\%) and birds $(77 \%)$. The survey showed that farmers considered the majority of long- and medium-stemmed varieties to be of high quality for making dibou (60\%) and sorou $(60 \%)$; only $28 \%$ of these varieties had a high quality for tchoukoutou preparation. Of the shortstemmed varieties, the majority were considered to have poor quality for making dibou $(63 \%)$, sorou $(50 \%)$ or tchoukoutou (63\%). Apparently, the quality demands for varieties to make tchoukoutou are higher than those for porridges. Clearly, most of the short-stemmed varieties are considered to deliver poor-quality food. The higher quality requirements of varieties for preparing tchoukoutou may be related to the way in which this product is made and to specific consumers' preferences. First, the suitability for malting (germination) is essential, and second, the seed should contain enough starch to yield an opaque beer with sufficient alcohol. ${ }^{3}$ These aspects should be taken into account when breeding varieties for tchoukoutou production. Another important aspect in breeding for tchoukoutou is the farmers' preferences for large seeds. Farmers justified their preferences for large seeds by a high yield of beer.

The data on colour preferences were not statistically different. The fact that not only red but also some white varieties produce tchoukoutou with a pink colour $^{3}$ may have contributed to this.

The correlations between recorded food quality and agromorphology traits showed that late-maturing varieties were judged to be more suitable than the 
Table 2. Relationship between food quality traits as expressed by farmers on a scale of 1-3 and agromorphological properties for long-medium stem varieties $(n=52)$

\begin{tabular}{|c|c|c|c|}
\hline Property ${ }^{a}$ & Dibou quality ${ }^{b}$ & Tchoukoutou quality ${ }^{b}$ & Sorou quality ${ }^{b}$ \\
\hline \multicolumn{4}{|l|}{ Maturity } \\
\hline Late $(n=28)$ & $2.71 \pm 0.66 a$ & $2.11 \pm 0.79 a$ & $2.64 \pm 0.62 a$ \\
\hline Early $(n=19)$ & $2.26 \pm 0.65 b c$ & $1.74 \pm 0.81 \mathrm{ab}$ & $2.11 \pm 0.88 \mathrm{bc}$ \\
\hline Intermediate $(n=5)$ & $2.20 \pm 0.45 a c$ & $1.00 \pm 0.0 b$ & $2.60 \pm 0.55 a c$ \\
\hline \multicolumn{4}{|l|}{ Grain size } \\
\hline Small $(n=8)$ & $2.00 \pm 0.0 a$ & $1.00 \pm 00 a$ & $1.5 \pm 0.53 a$ \\
\hline Medium $(n=19)$ & $2.32 \pm 0.82 a$ & $1.63 \pm 0.68 b$ & $2.42 \pm 0.69 b$ \\
\hline Large $(n=25)$ & $2.80 \pm 0.50 c$ & $2.32 \pm 0.75 c$ & $2.76 \pm 0.60 c$ \\
\hline \multicolumn{4}{|l|}{ Grain colour } \\
\hline $\operatorname{Red}(n=10)$ & $2.5 \pm 0.53 a b$ & $1.80 \pm 0.79 a b$ & $2.40 \pm 0.52 a b$ \\
\hline White $(n=21)$ & $2.33 \pm 0.8 \mathrm{ad}$ & $1.52 \pm 0.68 a$ & $2.29 \pm 0.85 a b$ \\
\hline Pink $(n=19)$ & $2.79 \pm 0.42 b$ & $2.37 \pm 0.76 b$ & $2.74 \pm 0.65 a$ \\
\hline Yellow $(n=2)$ & $1.50 \pm 0.71 \mathrm{~cd}$ & $1 \pm 00 \mathrm{a}$ & $1.50 \pm 0.71 \mathrm{cb}$ \\
\hline
\end{tabular}

${ }^{a} n=$ No. of varieties.

${ }^{b}$ Means \pm standard deviation; means with the same letter are not significantly different according to the LSD at the 0.05 level.

early varieties for the production of dibou and sorou (Table 2). This preference could be related to the consumers' preferences for products of high viscosity. ${ }^{19}$ In the case of tchoukoutou, differences in maturity are less important. However, it should be noted that some early varieties (e.g. natisoya or chamwoka) were judged to yield poor-quality beer. For all three products in the study, large-seeded varieties were preferred to medium- and small-seeded varieties. With respect to the preference for grain colour, the marks given by the farmers were always highest for pink followed by red, white and yellow. However, the differences are not always statistically significant. The colour preferences for the porridges follow the same order as for tchoukoutou. In contrast to tchoukoutou, colour defects in the porridges can be masked by adding specific ingredients such as the leaves of certain sorghum varieties to obtain a pink colour. Likewise, cassava chips are added to sorghum flour to correct the viscosity defect of some varieties.

\section{Genetic diversity within farmers' varieties and areas}

Seventy-two farmers' varieties of sorghum, of which 64 are of long-medium stem (type L) and eight of short stem (type S), were considered in the AFLP analysis. The short-stem (S) types were treated separately, because they appeared to form a separate and outlier group compared with the other (L) types (Fig. 1). The type $\mathrm{L}$ varieties were grouped by area of collection i.e. Banikoara, Djougou and Toucountouna. A total of 91 polymorphic AFLP bands were identified. The comparison of the Nei's genetic diversity $\left(H_{j}\right)$ between type $\mathrm{L}$ and $\mathrm{S}$ varieties indicates a relatively high genetic diversity within the short stem varieties $(0.378 \mathrm{vs}$ $0.1211-0.240)$ in spite of the restricted number of the short varieties $(n=8)$ included in the analysis (Table 3). Possible reasons for this are that most of the short varieties have less desirable properties (yellow or white colour, bitter taste) and, accordingly, are ranked by farmers as providing poor food quality. Some farmers declared that they maintained them in their fields because of their medicinal value. Consequently, they may have received less attention from farmers for selection and for exchange of material between farmers. In addition, because of their limited number and their distinctiveness in morphological characteristics (grain colour, panicle shape and form), farmers could easily distinguish them.

The gene diversity $\left(H_{j}\right)$ within an area was comparable (0.211-0.240) between areas of collection. Accordingly, $F_{\text {st }}$ among areas was lower than between the two types of sorghum (Table 4). However, the varieties collected in Banikoara were slightly less diverse in spite of their relatively high number. Sorghum is the

Table 3. Gene diversity statistics within sorghum groups

\begin{tabular}{|c|c|c|c|c|c|c|c|}
\hline Type & Area sampled & Code & No. of samples & $\begin{array}{l}\text { No. of polymorphic } \\
\text { loci }^{\mathrm{a}}\end{array}$ & $\begin{array}{c}\text { Proportion of } \\
\text { polymorphic loci (\%) }\end{array}$ & $H_{j}^{\mathrm{C}}$ & $H_{j}^{d}$ \\
\hline \multirow[t]{3}{*}{$\mathrm{L}$} & Banikoara & 1 & 29 & 66 & 72.5 & 0.211 & 0.184 \\
\hline & Djougou & 2 & 17 & 64 & 70.3 & 0.228 & 0.203 \\
\hline & Toucountouna & 3 & 18 & 67 & 73.6 & 0.240 & 0.216 \\
\hline S & Banikoara and Toucountouna & 4 & 8 & 85 & 93.4 & 0.378 & 0.387 \\
\hline
\end{tabular}

a No. of polymorphic loci at the $5 \%$ level, i.e. loci with allelic frequencies lying in the range $0.05-0.95$.

b Proportion of polymorphic loci at the $5 \%$ level.

${ }^{\mathrm{c}} H_{j}=$ expected heterozygosity (Nei's gene diversity) under Hardy-Weinberg genotypic proportions.

${ }^{\mathrm{d}}$ Assuming self-fertilisation $s=0.8\left[F_{\text {is }}=s(2-s)=0.67\right.$ under mixed mating]. 


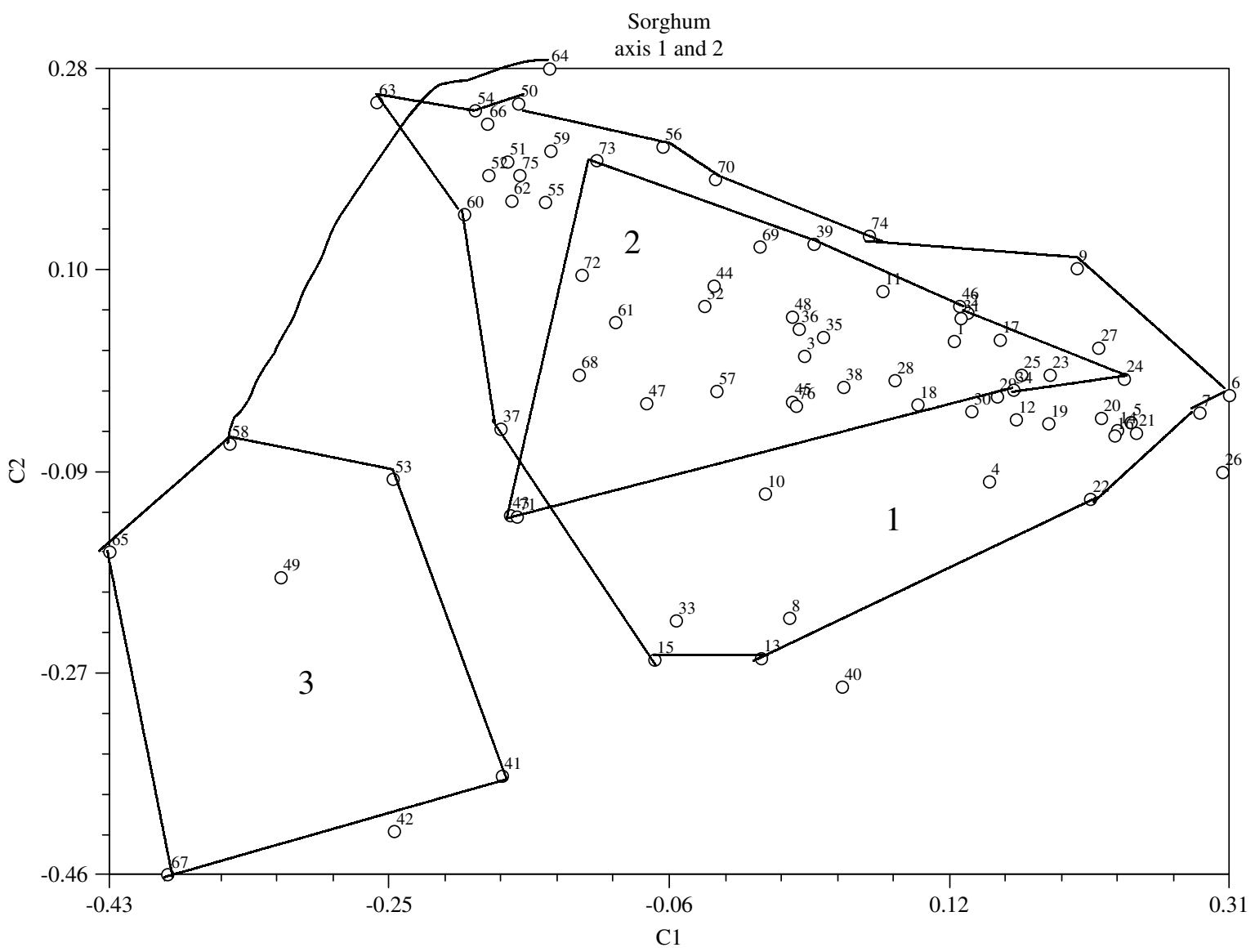

Figure 1. Principal coordinate analysis of the AFLP profiles showing all individual samples grouped by stem length: 1, long-stem varieties; 2, medium-stem varieties; 3 , short-stem varieties.

Table 4. Genetic differentiation among sorghum groups

\begin{tabular}{|c|c|c|c|c|c|c|}
\hline Comparison & No. of populations or groups & $H_{\mathrm{t}}^{\mathrm{a}}$ & $H_{\mathrm{w}}^{\mathrm{b}}$ & $H_{b}^{c}$ & $F_{\text {st }}$ & $N_{\mathrm{m}}{ }^{\mathrm{d}}$ \\
\hline Among sample areas & 3 & 0.248 & 0.227 & 0.021 & $0.086^{* *}$ & 2.66 \\
\hline $\begin{array}{l}\text { Between type } L \text { and } S(1,2,3 \\
\text { compared with } 4)\end{array}$ & 2 & 0.355 & 0.305 & 0.050 & $0.135^{* *}$ & \\
\hline Among the four groups & 4 & 0.303 & 0.264 & 0.038 & $0.126^{* *}$ & \\
\hline
\end{tabular}

a $H_{\mathrm{t}}=$ total gene diversity.

${ }^{\mathrm{b}} H_{\mathrm{w}}=$ mean gene diversity within areas (Nei's $H_{\mathrm{s}}$ ).

${ }^{c} H_{\mathrm{b}}=$ average gene diversity among areas in excess of that observed within areas.

${ }^{\mathrm{d}} N_{\mathrm{m}}=$ estimate of gene flow among areas; assuming random mating, Hardy-Weinberg equilibrium and $N_{\mathrm{m}}=\left(1 / F_{\mathrm{st}}-1\right) / 4$.

** $=$ significant at $P<0.01$.

major crop in Banikoara and it plays an important role in household food security. Farmers are always looking for better performing varieties and seed exchange between villages and farms is particularly common in this region, as reported by farmers. The name given to some varieties testifies to this. For example, the variety baniyani bears the name of the village from which it was imported, whereas the varieties bio-dahu and gbango bear the names of the farmers who introduced them in the villages where we collected them. At the same time, these varieties kept their initial name in their village of origin. Given this, many duplicated varieties may be present in the area of Banikoara and this may result in reduced gene diversity.

\section{Genetic differentiation and principal coordinate analysis}

High genetic differentiation $\left(F_{\mathrm{st}}\right)$ was found between the short and long-medium varieties (Table 4). This genetic differentiation would be consistent with the classification of farmers, who consider short varieties to be different from the other varieties based on their morphology and food properties. The level of genetic differentiation among areas was low but significant $\left(F_{\mathrm{st}}=0.086\right)$. The pairwise matrix of genetic differentiation (Table 5) showed high differentiation between varieties from Banikoara and Djougou whereas varieties from Toucountouna were found to be close to those from Banikoara 


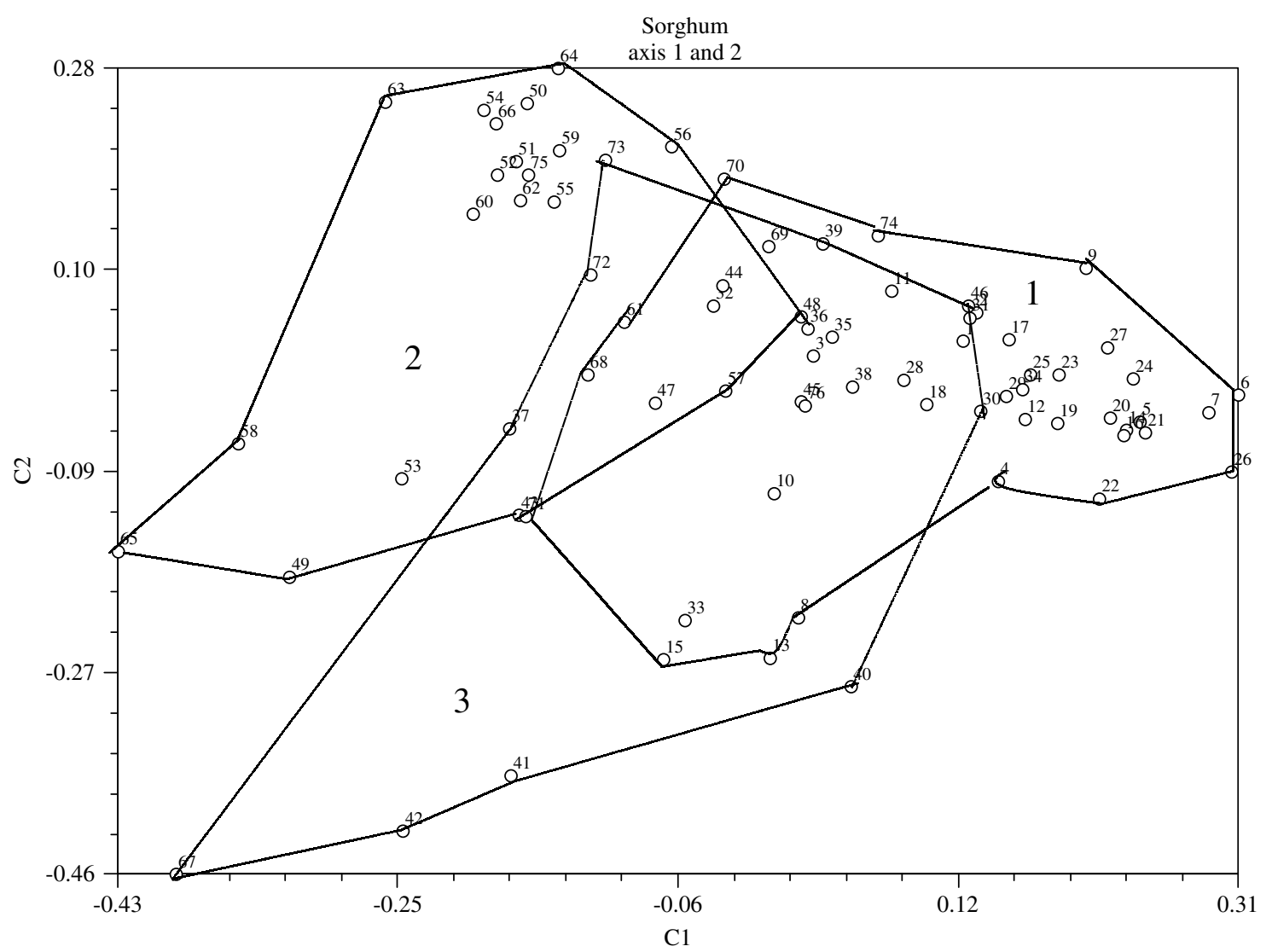

Figure 2. Principal coordinate analysis of the AFLP showing all individual samples grouped by region: 1, Banikoara; 2,Djougou; 3, Toucountouna.

Table 5. Pairwise matrix of genetic differentiation $\left(F_{\mathrm{st}}\right)$ among sorghum types and areas

\begin{tabular}{lllll}
\hline & \multicolumn{1}{c}{1} & \multicolumn{1}{c}{2} & \multicolumn{1}{c}{3} & 4 \\
\hline 1 & 0 & & & \\
2 & 0.150 & 0 & & \\
3 & 0.034 & 0.070 & 0 & 0 \\
4 & 0.165 & 0.170 & 0.135 & 0 \\
\hline
\end{tabular}

and Djougou. Considering the geographic distance between areas, Toucountouna is at mid-distance between Banikoara and Djougou. In a PCO analysis, there was a tendency for the varieties to distribute according to the areas of collection (Fig. 2), with large overlaps between the three areas investigated; and most extensively between samples from Banikoara and Toucountouna. On the other hand, the varieties with long and medium stems could not be separated whereas short-stem varieties were clearly differentiated (Fig. 1). To have an idea of the rate of exchange, 'gene flow' $\left(N_{\mathrm{m}}\right)$ among areas was estimated as $N_{\mathrm{m}}=\left(1 / F_{\mathrm{st}}-1\right) / 4$, even though not all assumptions (random mating population, no selection, etc.) are met. The value of 2.66 'dispersers' per generation corresponds to a fair but certainly not unlimited level of gene flow between communities, which may be responsible for a low level of differentiation between areas. In the present study, seed exchanges between farmers from different communities could be the main agent for gene flow between areas. Indeed, gene flow through trade may lead to an isolation-by-distance pattern of genetic differentiation with increasing geographic distance. ${ }^{20}$ The present sampling strategy, which focused on farmers in the neighbourhood of three regions and did not include farmers at many different geographical distances, was not suited to test for an isolation-by-distance in Bénin.

\section{Relationship between genetic and the end-use quality of varieties}

AMOVA was performed to explore the relationship between the genetic variance and food quality and also agro-morphological traits of the varieties. No significant correlation could be detected between the genetic distance of the varieties and the differences in their food quality as expressed by the farmers. This suggests that farmers do not select varieties from different gene pools for specific food purposes. Nevertheless, with respect to the morphological properties, the grain colour partitioned into four subgroups (red, pink, white and yellow), the stem length (long, medium, short) and the panicle shape (loose, compact) were found to be significantly correlated with the genetic structure among the varieties. The genetic distance (pairwise $F_{\mathrm{st}}$ ) between subgroups ranges from 0.038 to 0.058 for colour, from 0.011 to 0.211 (long vs short) for stem length, whereas compact and loose panicle varieties had a genetic distance of 0.069. Even though the genetic distances between subgroups were statistically significant, only 
$4.66-10.93 \%$ of the total molecular variation is attributed to the among-subgroup genetic variation for these morphological properties. The within-subgroup variation therefore accounts for the major part of the molecular variation observed.

The genetic distance of the varieties did not correlate with differences in some important agronomic traits such as resistance to bird attack, striga or drought. Indeed, these characteristics vary among local varieties within one village or even between neighbouring farms, as much as across the whole study, and may be subject to trials in further investigations to screen varieties for important agronomic characteristics.

\section{CONCLUSION: IMPLICATIONS FOR CROP CONSERVATION AND BREEDING}

The present study made use of farmers' knowledge and molecular markers to elucidate the diversity in farmers' varieties of sorghum in northern Bénin. Farmers reported a large number of varieties in which different end-use properties and agronomic traits are spread, reflecting the different environment and consumers' demands with which they are confronted. The molecular marker study revealed an appreciable genetic diversity between farmers' varieties. By differentiating short-from long-mediumstemmed varieties, the AFLP technique supports the classification of the farmers, who regard these varieties to be different. The short varieties may have been imported or traded recently and therefore there may not have been time to select a subset of the variation. Further investigations may be needed to clarify the history of this group of varieties.

Important correlations have been found between the food quality of the varieties and their agromorphological traits, whereas the correlation between neutral genetic data and food quality is poor, as studied with the chosen primer combinations. This most likely reflects the fact that farmers select or appreciate varieties from one common gene pool (for long- and medium-stemmed sorghum). The between-area difference in genetic similarities suggests trade or exchange between regions, albeit constrained by distance. To quantify this, a study would be needed that correlates genetic distance with a measure of travelling time between farmers. Also, some morphological traits exhibited a gradient from the northern-most village to the south and showed a correlation with the genetic differentiation of varieties from the three regions.

Crop selection at the farmer level is a multipurposeoriented process. Both consumers' preferences and the environmental constraints influence the creation of diversity. The presence in farmers' collections of varieties that combine various properties could be of interest for breeders. The farmers' preference for long-stemmed varieties is justified not only by the food of good quality they could yield, but also because the production of biomass is important for fuel and construction material supply. The striga-resistant varieties (chassisoya, shakarabokuru, lamrozo) are also stated to tolerate low-fertility soils and to possess high food quality properties. Interestingly, the genetic similarity between chassisoya and shakarabokuru is low $(<0.90)$, which suggests that these varieties could be genetically distant from each other. Striga species are obligate parasite plants that attack the roots of agronomically important crops, including sorghum, causing enormous crop losses and thereby affecting the livelihood of over 100 million people in Africa. ${ }^{21}$ The identification of resistant varieties to striga within farmers' gene pools could facilitate breeding programmes aiming at developing new varieties against this hemi-parasite. In the same way, the maintenance and cultivation of poor food quality varieties are connected with their medicinal properties (e.g. sotakama, kassassahan) or their strategic role for household food security (e.g. early-maturing varieties).

The findings of the present study provide background information that could be useful for national core collection and breeding of sorghum. Efforts to conserve and improve this germplasm should make use of both genetic variability and the farmers' knowledge to identify superior germplasm in terms of both agro-morphological properties and food quality traits. Farmers reported that a number of varieties are disappearing. The fact that we could not collect all the varieties identified by farmers is partly due to this trend. Also, urbanisation phenomena seem to contribute to the loss of knowledge about the varieties. For example, in Parakou - the major urban area of northern Bénin - farmers/consumers know relatively few varieties that they distinguish on the basis of colour. When species die out, the cultural practices and language connected with them also disappear. ${ }^{14}$

Further investigations, including other sorghum farming areas, are recommended for systematic collection of the existing farmers' varieties. Because of the human-environment interaction in the generation of diversity, both in situ and ex situ conservation are recommended for the preservation of the present germplasm.

\section{ACKNOWLEDGEMENTS}

Financial support provided by Wageningen University through the North-South Interdisciplinary Research and Education Fund (INREF) and by the International Foundation for Science (grant E-3736) is gratefully acknowledged. Jeroen Werij is thanked for testing the AFLP primer pairs, Linda Kodde for running the AFLP gels and Dirk Visser for scoring them.

\section{REFERENCES}

1 Hounhouigan DJ, La valorisation des céréales locales pour les marchés urbains en Afriques de l'Ouest: les atouts, contraintes et perspectives, in Food-based Approaches for a Healthy Nutrition in West Africa; Proceedings of the 2nd International Workshop, ed. by Brouwer ID, Traore AS and Treche S. University 
of Ouagadougou, Ouagadougou; Institute for Development Research, Montpellier; Wageningen University, Wageningen; Food and Agriculture Organization, Rome, Ouagadougou, pp. 359-368 (2004)

2 Uptmoor R, Wenzel W, Friedt W, Donaldson G, Ayisi K and Ordon F, Comparative analysis on the genetic relatedness of Sorghum bicolor accessions from southern Africa by RAPDs, AFLPs and SSRs. Theor Appl Genet 106:1316-1325 (2003).

3 Kayodé PAP, Adégbidi A, Linnemann AR, Nout MJR and Hounhouigan DJ, Consumers' quality perception of farmers' varieties of sorghum and derived foods in Benin, in Food-based Approaches for a Healthy Nutrition in West Africa; Proceedings of the 2nd International Workshop, ed. by Brouwer ID, Traore AS and Treche S. University of Ouagadougou, Ouagadougou; Institute for Development Research, Montpellier; Wageningen University, Wageningen; Food and Agriculture Organization, Rome, Ouagadougou, pp. 91-105 (2004).

4 Nkongolo KK and Nsapato L, Genetic diversity in Sorghum bicolor (L.) Moench accessions from different ecogeographical regions in Malawi assessed with RAPDs. Genet Resour Crop Evol 50:149-156 (2003).

5 Grubben GJH and Partohardjono S, Plant Resources of South-east Asia. No 10: Cereals. Backhuys Publishers, Leiden (1996).

6 Tanksley SD and McCouch R, Seed bank and molecular maps: unlocking genetic potential from the wild. Science 277:1063-1066 (1997).

7 Zhang D, Cervantes J, Huaman Z, Carey E and Ghislain M, Assessing genetic diversity of sweet potato (Ipomoea batatas (L.) Lam.) cultivars from tropical America using AFLP. Genet Resour Crop Evol 47:659-665 (2000).

8 IPGRI, Geneflow. Une Publication sur les Ressources Phytogénétiques de la Terre. Institut International des Ressources Phytogénétiques, Rome (1993).

9 Kebebew F, Tsehaye Y and McNeilly T, Morphological and farmers cognitive diversity of barley (Hordeum vulgare L. [Poaceae]) at Bale and North Shewa of Ethiopia. Genet Resources Crop Evol 48:467-481 (2001).

10 Van Leur JA and Gebre H, Diversity between some Ethiopian farmers' varieties of barley and within these varieties among seed sources. Genet Resour Crop Evol 50:351-357 (2003).

11 Vos P, Hogers R, Bleeker M, Reijans M, Van der Lee T, Hornes M, Frijters A, Pot J, Peleman J, Kuiper $M$ and
Zabeau M, AFLP: a new technique for DNA fingerprinting. Nucleic Acids Res 23:4407-4414 (1995).

12 Maciel FL, Echeverrigaray S, Gerald LTS and Grazziotin FG, Genetic relationships and diversity among Brazilian cultivars and landraces of common beans (Phaseolus vulgaris L.) revealed by AFLP markers. Genet Resour Crop Evol 50:887-893 (2003).

13 Gupta PK, Varshney RK, Sharma PC and Ramesh B, Molecular markers and their applications in wheat breeding. Plant Breeding 118:369-390 (1999).

14 Negash A and Niehof A, The significance of Enset culture and biodiversity for rural household food and livelihood security in southwestern Ethiopia. Agric Hum Values 21:61-71 (2004).

15 Fulton E, Chunwongse J and Tanksley SD, Microprep protocol for extraction of DNA from tomato and other herbaceous plants. Plant Mol Biol Rep 13:207-209 (1995).

16 Myburg AA, Remington DL, O'Malley DM, Sederoff RR and Whetten RW, High-throughput AFLP analysis using infrared dye-labeled primers and an automated DNA sequencer. Biotechniques 30:348-357 (2001).

17 Vekemans X, Beauwens T, Lemaire $M$ and Roldan-Ruiz I, Data from amplified fragment length polymorphism (AFLP) markers show indication of size homoplasy and fragment size. Mol Ecol 11:139-151 (2002).

18 Excoffier L, Smouse PE and Quattro JM, Analysis of molecular variance inferred from metric distances among DNA haplotypes: application to human mitochondrial DNA restriction data. Genetics 131:479-491 (1995).

19 Kayode PAP, Adégbidi A, Linnemann AR, Nout MJR and Hounhouigan DJ, Quality of farmers' varieties of sorghum and derived foods as perceived by consumers in Benin. Ecol Food Nutr 44:271-294.

20 Adin A, Weber JC, Sotelo Montes C, Vidaurre H, Vosman $B$ and Smulders MJM, Genetic differentiation and trade among populations of peach palm (Bactris gasipaes Kunth) in the Peruvian Amazon - implications for genetic resource management. Theor Appl Genet 108:1564-1573 (2004).

21 Botanga CJ, Kling JG, Berner DK and Timko MP, Genetic variability of Striga asiatica (L.) Kuntz based on AFLP analysis and host-parasite interaction. Euphytica 128: 375-388 (2002). 